\title{
Sea ice cover affects inter-annual and geographic variation in growth of the Arctic cockle Clinocardium ciliatum (Bivalvia) in Greenland
}

\author{
Mikael Kristian Sejr ${ }^{1, *}$, Martin Emil Blicher ${ }^{1,2}$, Søren Rysgaard ${ }^{2}$ \\ ${ }^{1}$ National Environmental Research Institute, Department of Marine Ecology, University of Aarhus, Vejlsøvej 25, \\ 8600 Silkeborg, Denmark \\ ${ }^{2}$ Greenland Institute of Natural Resources, Kivioq 2, PO Box 570, 3900 Nuuk, Greenland
}

\begin{abstract}
Sea ice exerts a strong influence on Arctic marine primary production, thereby influencing food availability for secondary producers. Food availability is recognized as one of the primary constraints on macrobenthic growth and production. Thus, it may be expected that spatial and temporal variability in Arctic sea ice cover influencing primary productivity could translate to the next trophic level: the benthic secondary producers. To test whether sea ice cover is coupled to the annual production of Arctic benthos, we measured annual growth increments in the shell of the bivalve Clinocardium ciliatum to (1) compare average individual growth rates along a climate gradient from sub-Arctic to high-Arctic Greenland, and (2) produce time series of inter-annual variation in bivalve growth at sites with different sea ice conditions. A significant difference between average individual growth rates between the different sites was found. This geographic variation in growth performance was correlated to the average productive open-water (ice-free) period estimated from sea ice data obtained from satellites between 1979 and 2003. At locations with low to moderate sea ice cover, growth rates ranged from 80 to $100 \%$ of the fastest growing sites. At sites with pronounced sea ice cover, bivalve growth was reduced to 35 to $45 \%$ of the maximum growth rates. At these 2 sites the year-to-year variation in bivalve growth correlated negatively with inter-annual variation in local sea ice cover. We suggest that, in the Arctic, bivalve growth is governed by food availability. At sites with pronounced sea ice cover, food availability may be linked to sea ice dynamics through the bottom-up regulation exerted by sea ice on phytoplankton production, which renders such areas especially susceptible to future climate change.
\end{abstract}

KEY WORDS: Bivalve $\cdot$ Annual growth $\cdot$ Arctic $\cdot$ Sea ice $\cdot$ Sclerochronology $\cdot$ Marine $\cdot$ Climate Resale or republication not permitted without written consent of the publisher

\section{INTRODUCTION}

Reduction in sea ice area distribution and thickness is one of the most significant effects of the recent warming of the Arctic. Data from 1979 to 2008 show a negative trend in Arctic sea ice extent with a reduction of $2.8 \%$ per decade in March and $11 \%$ per decade in September (Richter-Menge et al. 2008). In September 2007, a record low sea ice cover was observed, which was $39 \%$ below the September mean from 1979 to 2000 (National Snow and Ice Data Center 2007). Outputs from atmosphere-ocean general circulation mod- els predict a 15 and a $61 \%$ reduction in sea ice extent (average of 14 model outputs) in March and September, respectively, in the Arctic at the end of this century. Additionally, 7 of 14 models predict that the Arctic Ocean will be ice-free in late summer at the end of the 21st century (Arzel et al. 2006). In Arctic marine ecosystems, an important influence of sea ice is that it impedes light penetration into the water column and hence controls primary production, especially during spring. Sea ice thereby determines the timing of the spring bloom and the length of the productive openwater period and, thus, potentially the size of the 
annual primary production (Rysgaard et al. 1999, Arrigo et al. 2008).

On the Arctic sea floor, the biomass of macrobenthos often reflects the productivity of the overlying water column (Grebmeier et al. 1989, Renaud et al. 2007) and benthic growth and production are generally considered to be regulated by food availability (Clarke 1988, Clarke \& Fraser 2004, Sejr et al. 2004); thus, it may be expected that patterns of Arctic sea ice cover not only affect primary production, but may also affect benthic secondary production. That geographical variation in ice cover can affect annual growth rates of macrobenthos was recently shown in sea urchin Strongylocentrotus droebachiensis collected around Greenland (Blicher et al. 2007).

The aim of this study was to test the proposed coupling between sea ice and growth rates of macrobenthos. We attempt to do this by measuring annual shell growth in the Arctic cockle Clinocardium ciliatum (Fabricius, 1780) and comparing it to information on sea ice cover derived from satellites. Two aspects of the potential coupling between sea ice and benthos were tested: (1) Whether spatial variation in average individual growth between different sites could be related to differences in the extent of seasonal sea ice cover. This was tested by comparing bivalve growth along a climatic gradient in Greenland $\left(64^{\circ} \mathrm{N}\right.$ to $\left.76^{\circ} \mathrm{N}\right)$. (2) Whether inter-annual variation in bivalve growth at 5 different locations could be related to local sea ice conditions from 1979 to 2003 . This was tested by reconstructing past variation in bivalve growth from shell increment analysis.

\section{MATERIALS AND METHODS}

Study sites. The study was conducted at sites representing a gradient of increasing sea-ice cover from the sub-Arctic to the high-Arctic (Fig. 1). Sites were visited between 1998 and 2007. Geographic positions and sampling depths are given in Table 1.

Ice data and climatic indices. Site-specific ice cover was based on satellite data from 1979 to 2003 extracted from Gloerson et al. (1990) and Maslanik \& Stroeve (2004). Data are presented as a sea ice index (range: 0 to 1), with low values indicating little or no sea ice and high values indicating full ice cover. Data were extracted on a local scale at the position of bivalve collection in an area covering 4 pixels with each pixel covering $25 \times 25 \mathrm{~km}$. To make sure that reasonable ice data could be extracted from just 4 pixels, data were compared to regional data extracted from 18 (Disko Bay) and 54 pixels (Greenland Sea off Young Sound). For each site, the productive open-water period was calculated as the average number of days with open water and more than $6 \mathrm{~h}$ of daylight, below which primary production was assumed to be $\sim 0$ due to light limitation at these high latitudes (Rysgaard et al. 1999).

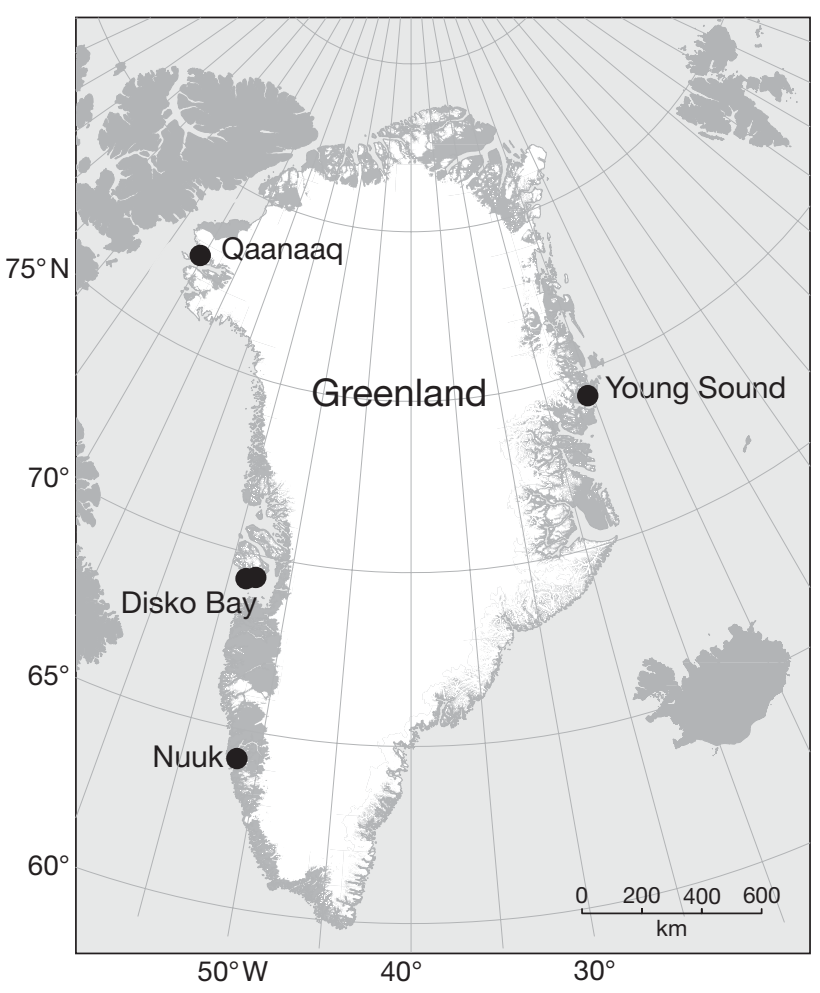

Fig. 1. Clinocardium ciliatum. Location of the different sampling sites

Table 1. Clinocardium ciliatum. For each sampling site: position; depth; growth performance $\left(G_{\max }\right)$ estimated as the maximum annual shell growth of the chondrophore region; duration of the productive open-water period (POWP)

\begin{tabular}{|c|c|c|c|c|c|c|c|c|}
\hline \multirow[t]{2}{*}{ Site } & \multicolumn{2}{|c|}{ Position } & \multirow{2}{*}{$\begin{array}{c}\text { Depth } \\
\text { (m) }\end{array}$} & \multirow[t]{2}{*}{$\mathrm{n}$} & \multirow{2}{*}{$\begin{array}{c}G_{\max } \\
\left(\mu \mathrm{yr}^{-1}\right)\end{array}$} & \multirow[t]{2}{*}{$95 \% \mathrm{CI}$} & \multirow{2}{*}{$\begin{array}{c}G_{\max } \\
(\% \text { of max })\end{array}$} & \multirow{2}{*}{$\begin{array}{l}\text { POWF } \\
\text { (d) }\end{array}$} \\
\hline & $\mathrm{N}$ & W & & & & & & \\
\hline Qaanaaq & $76^{\circ} 32^{\prime}$ & $68^{\circ} 45^{\prime}$ & $25-40$ & 29 & 166.9 & 22.4 & 43 & 90 \\
\hline Young Sound & $74^{\circ} 18^{\prime}$ & $20^{\circ} 15^{\prime}$ & $20-35$ & 29 & 136.3 & 9.9 & 35 & 85 \\
\hline Disko Bay A & $69^{\circ} 15^{\prime}$ & $53^{\circ} 34^{\prime}$ & $25-45$ & 39 & 347.9 & 36.1 & 89 & 186 \\
\hline Disko Bay B & $69^{\circ} 14^{\prime}$ & $53^{\circ} 33^{\prime}$ & $25-45$ & 35 & 314.8 & 23.4 & 81 & 186 \\
\hline Nuuk & $64^{\circ} 07^{\prime}$ & $51^{\circ} 38^{\prime}$ & $50-60$ & 27 & 389.4 & 40.9 & 100 & 290 \\
\hline
\end{tabular}


Open water was defined as $<50 \%$ sea ice cover (see Blicher et al. 2007). To describe the inter-annual variation in sea ice cover for each site, we calculated, for both local and regional data, the summer mean index defined as mean sea ice index (1979 to 2003) during the period with a minimum of $6 \mathrm{~h}$ of daylight.

The relation between the inter-annual variation in bivalve growth and the annual means of the Arctic Oscillation (AO) index and the Arctic Climate Regime Index (ACRI) was also tested. As in the study of Ambrose et al. (2006), we used 2-yr running means of climatic indices as well as a 1-yr lag to account for the time necessary for physical processes to be reflected in shell growth. Data on $\mathrm{AO}$ were obtained from www.cpc.ncep.noaa.gov/ products/precip/CWlink/daily_ao_index/ao_index.html and ACRI from Proshutinsky \& Johnson (1997) and A. Proshutinsky (pers. comm. for updated index).

Bivalve collection, preparation, and measurements. Upon collection, cockles were washed and stored in the freezer and transported to the lab for further analysis. This species produces clearly separated growth increments, which are assumed to represent annual growth based on the strong seasonal influence on food availability in the Arctic and previous studies from other Arctic species (Sejr et al. 2002a, Ambrose et al. 2006) and from the same genus (Goshima \& Noda 1992). Both externally on the shell and internally in the hinge region, narrow dark bands ('winter rings') are formed during the winter. In between the winter rings there are wider increments representing the summer shell growth. The widths of the summer increments in the chondrophore section of the shell were measured in this study. All specimens were caught alive, which means that the last increment was formed during the year of collection. By counting backwards, each increment width could be assigned to a particular calendar year. Increments were analysed in chondrophore sections of the shell to produce both estimates of growth performance and to reconstruct time series of interannual growth variation. The flesh was removed from the shell and the right shell was cut in 2 through the umbo along the axis of maximum growth according to Sejr et al. (2002b). One half of the right shell was then embedded in epoxy (Epofix; Struers, Denmark) and polished and etched with acid as described by Sejr et al. (2002b). Increment widths were analyzed under a dissecting microscope (magnification 10 to $100 \times$ ) and measurements were performed on digital images (Fig. 2) of the chondrophore using the software ImageJ ver. 1.33.

In order to test the reliability and precision of the reconstructed time series, we also analysed external summer increments visible on the outer surface of the shells collected at 2 sites in Disko Bay. Here, increment widths were measured to the nearest $0.1 \mathrm{~mm}$ with vernier callipers as in Tallqvist \& Sundet (2000).

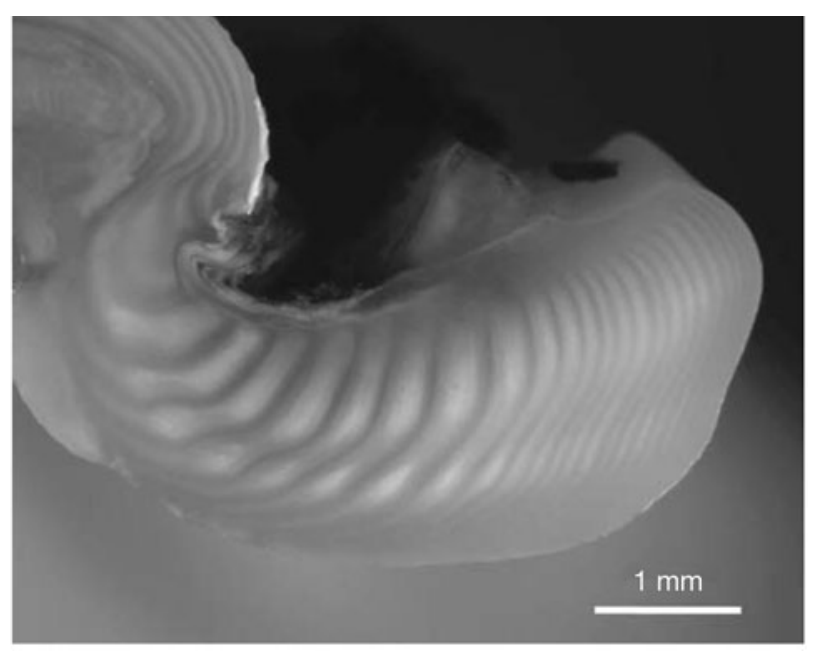

Fig. 2. Clinocardium ciliatum. Growth increments in the chondrophore section of the shell of the Arctic cockle

Spatial variation in growth. To compare growth between the different sites, we used the maximum increment of the chondrophore $\left(G_{\max }\right)$, i.e. the widest average summer increment (see Fig. 5a) was used as an estimate of growth performance. Growth rates were also evaluated by comparing the von Bertalanffy growth equations (see below).

Reconstructed time series of bivalve growth. The annual shell growth in bivalves is highly age dependent, typically decreasing with age (e.g. Sejr et al. $2002 \mathrm{~b}$, this study). This trend must be removed to allow comparison of growth between age classes and construction of time series. The shell growth can be modelled by the generalised von Bertalanffy growth function:

$$
L_{t}=L_{\infty} \times\left(1-\mathrm{e}^{-K\left(t-t_{0}\right)}\right)^{D}
$$

where $L_{t}$ is the shell length at age $t_{i} L_{\infty}$ is the asymptotic shell length; $K$ is the annual growth coefficient; and $D$ is the shape parameter determining if growth is more or less sigmoid. This growth model was fitted to summed increments-at-age data from each site in order to describe the 'mean' growth. To remove agedependence, a growth index was constructed by dividing measured increment growth by the growth predicted from the fitted von Bertalanffy growth equation:

$$
\mathrm{GI}_{t}=\frac{M_{(\mathrm{obs}) t}}{M_{(\mathrm{pred}) t}}
$$

where $\mathrm{GI}_{t}$ is the summer growth index for a single individual at age $t, M_{\text {(obs) } t}$ is the observed increment width at age $t$, and $M_{\text {(pred) } t}$ is the predicted increment width from the fitted von Bertalanffy growth equation. This method of removing the age-related growth trend is known as detrending and was developed in studies of 
tree rings and subsequently adapted for the study of growth increments in bivalves (Schöne 2003, Witbaard et al. 2003). The year-by-year record of relative growth indices $\left(\mathrm{GI}_{t}\right)$ for each individual were then transformed into a standardised growth index (SGI) by subtracting the mean $\left(\mathrm{GI}_{\text {mean }}\right)$ across years for that individual and dividing by the standard deviation of the mean $\left(\mathrm{GI}_{\mathrm{SD}}\right)$ :

This ensures that results from each individuals are standardised to their own mean and standard deviation and allows particularly fast and slow individuals to be directly compared. Finally, we calculated the mean SGI for each calendar year by averaging across all individuals. Standardisation removes the correlation between mean and variance and allows SGIs of young and old specimens to be compared directly (Schöne 2003). The SGI index is therefore a year-by year record of whether growth, i.e. summer increment width, in a specific year was higher $(\mathrm{SGI}>0)$ or lower $(\mathrm{SGI}<0)$ compared with the mean of the entire period. As the SGI index is calculated back in time, it is based on decreasing number of (old) individuals. We only used SGI values based on 5 or more individuals. For all sites,

$$
\mathrm{SGI}=\frac{\left(\mathrm{GI}_{t}-\mathrm{GI}_{\text {mean }}\right)}{\mathrm{GI}_{\mathrm{SD}}}
$$

the SGI index was calculated based on increments in the hinge region. In addition, for the Disko Bay sites, the SGI index was calculated based on increments visible directly on the shell surface. We thereby produced duplicate time series for each of the Disko Bay sites used in order to estimate the precision and reliability of the method. A total of 91 (Disko Bay A) and 87 (Disko Bay B) individuals were used to produce time series based on external increments. Time series of SGI were related to sea ice and climate indices using the Pearson correlation coefficient.

\section{RESULTS}

\section{Sea ice}

High correlation between local and regional sea ice data confirmed that representative data on local ice conditions could be extracted from a few pixels (data not shown). The average $\mathrm{R}^{2}$ from correlations between local and regional ice data was 0.92 . From the average seasonal change (1979 to 2003) in sea ice and daily daylight hours, we estimated the average productive open-water period (POWP) for each site (Fig. 3).

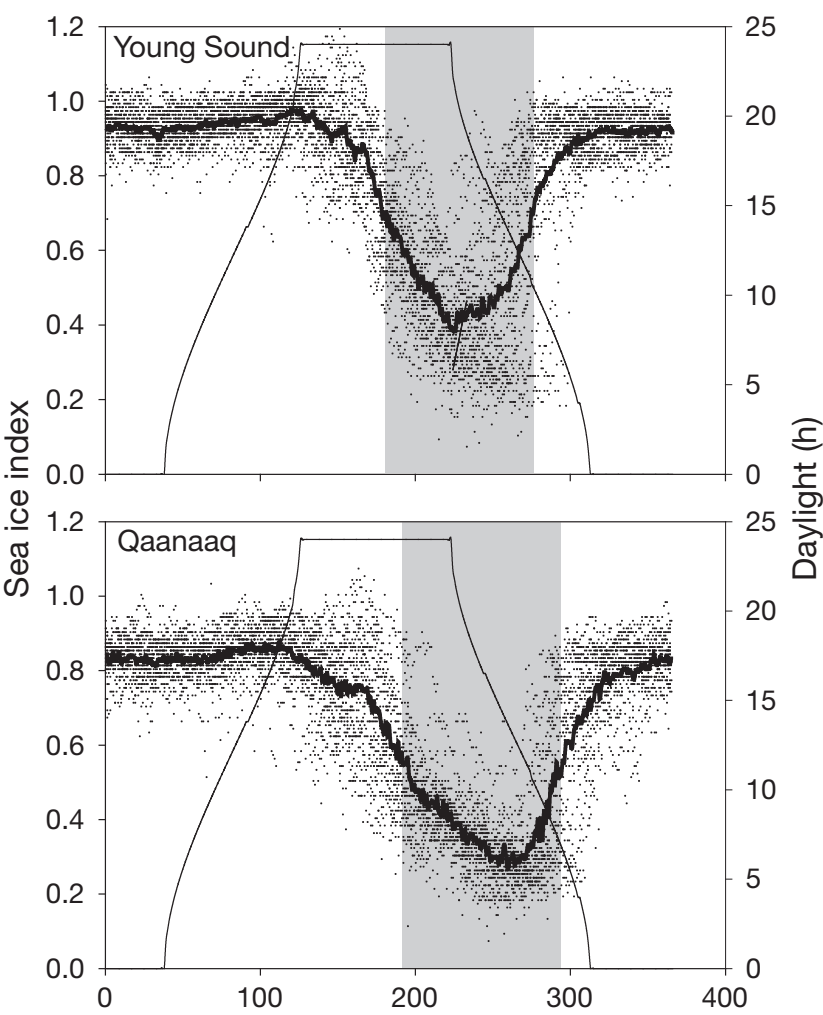

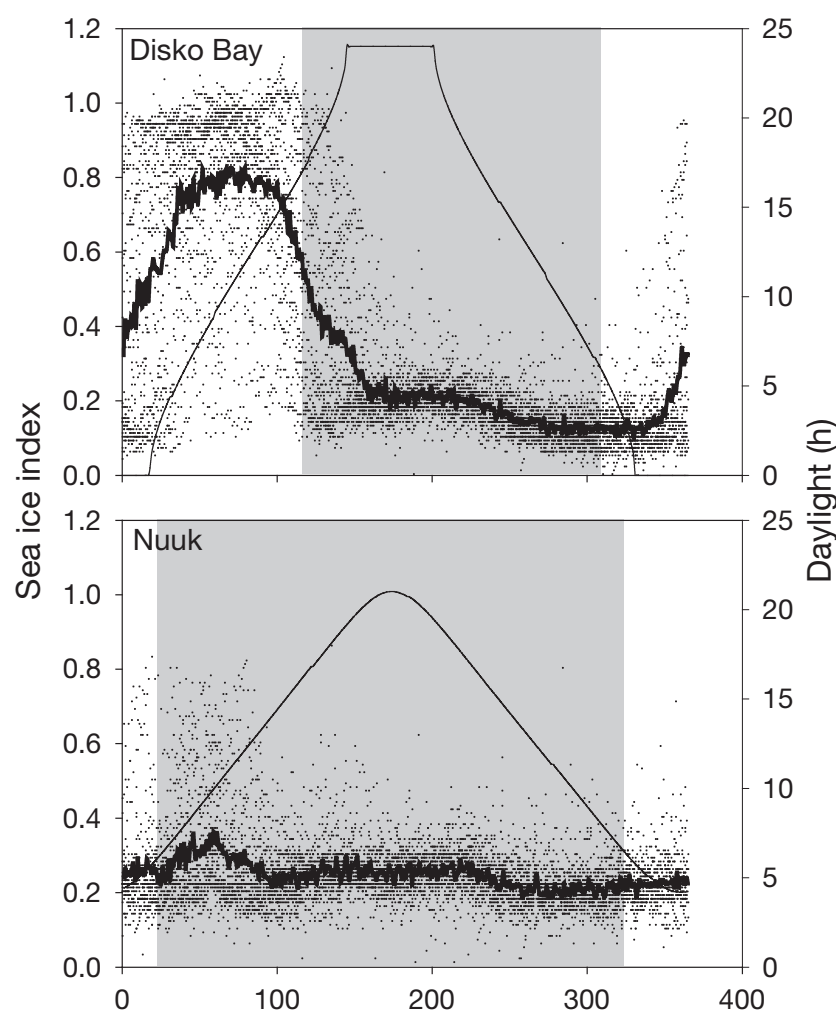

Day of the year

Fig. 3. Seasonal variation in daily sea ice index obtained from satellites: single-day observations (dots); average seasonal variation (thick line); daylight variation (thin line). Minimum index values correspond to ice-free water. Grey areas show average productive open-water period defined as days with average sea ice index $<50 \%$ of winter maximum, and minimum $6 \mathrm{~h}$ of daylight 
Qaanaaq and Young Sound were estimated to have 90 and $85 \mathrm{~d}$, respectively, of open water during the productive season while Nuuk had 290 (Table 1). In Nuuk, the POWP was not constrained by sea ice. The sites can be divided into 2 categories: Arctic sites with a permanent ice cover in winter (Qaanaaq and Young Sound) where the POWP is highly restricted by sea ice, and
Table 2. Clinocardium ciliatum. Von Bertalanffy growth equation parameters (defined in 'Materials and methods') fitted to data (see Fig. 5B), with $\pm 95 \%$ CI values given in parenthesis

\begin{tabular}{|lccccc|}
\hline Location & $\begin{array}{c}L_{\infty} \\
(\mathrm{mm})\end{array}$ & $\begin{array}{c}K \\
\left(\mathrm{yr}^{-1}\right)\end{array}$ & $\begin{array}{c}t_{0} \\
(\mathrm{yr})\end{array}$ & $D$ & $\mathrm{R}^{2}$ \\
\hline Qaanaaq & $2.023(0.042)$ & $0.061(0.006)$ & $1.750(0.148)$ & $0.067(0.050)$ & 0.98 \\
Young Sound & $1.608(0.034)$ & $0.110(0.018)$ & $0.740(0.494)$ & $1.004(0.220)$ & 0.99 \\
Disko Bay A & $3.612(0.038)$ & $0.175(0.012)$ & $0.585(0.328)$ & $1.820(0.360)$ & 0.99 \\
Disko Bay B & $4.152(0.063)$ & $0.167(0.010)$ & $0.753(0.304)$ & $1.774(0.226)$ & 0.99 \\
Nuuk & $5.461(0.052)$ & $0.13(0.008)$ & $1.368(0.164)$ & $1.647(0.202)$ & 0.99 \\
\hline
\end{tabular}

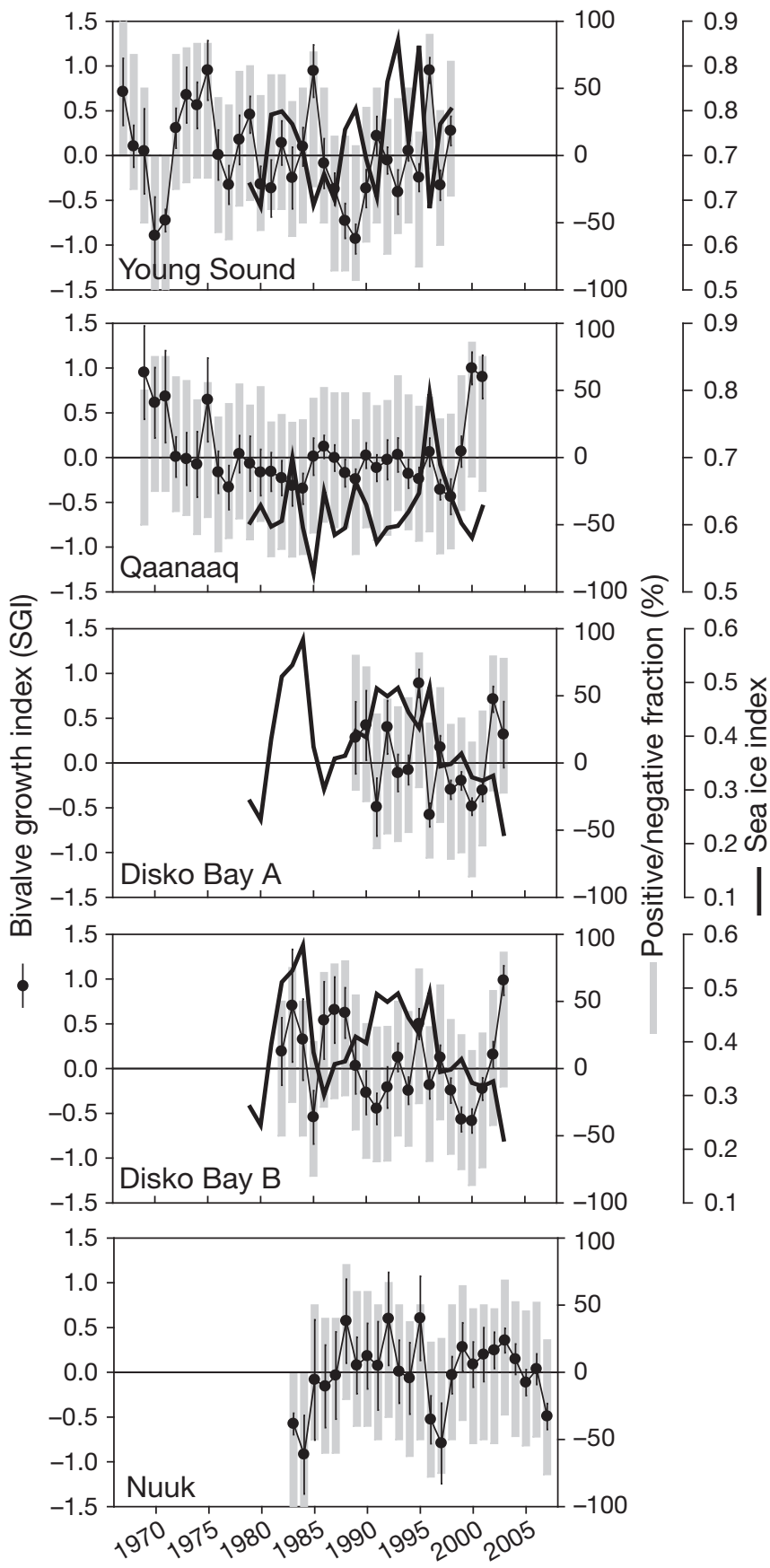

sub-Arctic sites (Disko Bay and Nuuk) where ice cover is variable even during winter and where sea ice only plays a minor role for the productive period. For Young Sound, the estimated average POWP of $85 \mathrm{~d}$ was confirmed by annual on-site observations since 1950 (Rysgaard \& Glud 2007). Inter-annual variation in summer sea ice index for Qaanaaq, Young Sound and Disko Bay (Fig. 4) show some degree of synchrony between sites but linear correlations were not significant. All 3 locations show a general decreasing trend from 1996 to 2003. At Nuuk, sea ice cover was too low in summer to calculate inter-annual variation.

\section{Spatial variation in bivalve growth}

The mean width of internal shell increments in the chondrophore (Fig. 5a) showed a typical bivalve growth pattern with strong effect of age on annual growth rate. The largest maximum increment width, $\left(G_{\max }\right)$ was found at Nuuk. The $G_{\max }$ in specimens from Young Sound and Qaanaaq were only 35 and $43 \%$, respectively, of that in specimens from the Nuuk site (Table 1). By adding up increment widths, the average individual growth at each of the locations was estimated (Fig. 5b), showing reduced growth in Young Sound and Qaanaaq and maximum growth in Nuuk. Parameters of the fitted von Bertalanffy growth equations are shown in Table 2 . The growth parameter, $K$, is lower in Nuuk compared to the Disko Bay locations. This is mainly a result of the higher maximum age found at Nuuk. Furthermore, $G_{\max }$ showed a significant relationship (Fig. 6) with the POWP $\left(G_{\max }=0.32 \times\right.$ [POWP] $\left.+14.3, \mathrm{p}<0.01, \mathrm{R}^{2}=0.95\right)$. When $G_{\max }$ values for the sea urchin Strongylocentrotus droebachiensis were included (recalculated from Blicher et al. 2007)

Fig. 4. Clinocardium ciliatum. Reconstructed time series of variation in annual shell growth (-๑) at 5 locations. Average $( \pm 1 \mathrm{SE})$ and percentage of the collected specimens with positive/negative index values (grey bars). Inter-annual variation in summer sea ice index (-) at 3 locations in Greenland. Sea ice at Nuuk was too low in summer to calculate index values 

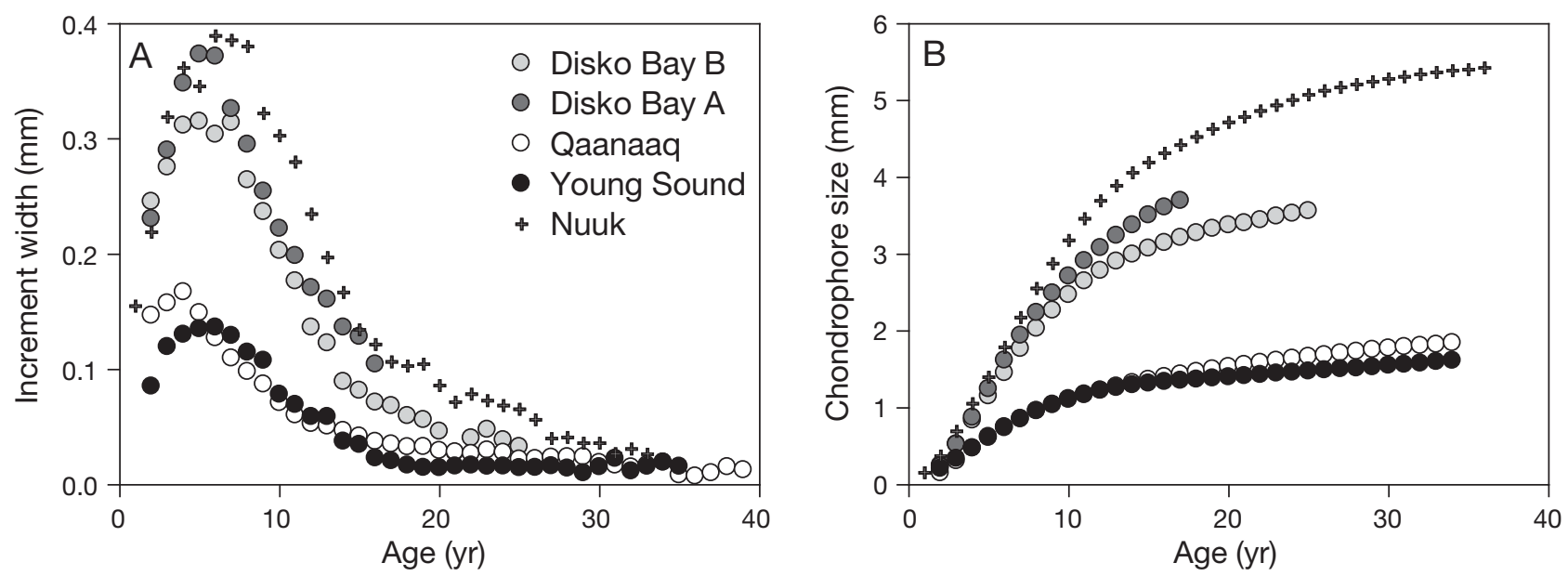

Fig. 5. Clinocardium ciliatum. For 5 sites in Greenland: (A) Average width of summer increment in the chondrophore section of the bivalve; (B) Average growth curves obtained by summing up individual increments shown in (A)

there was a clear tendency (Fig. 6, solid line) in sites with a long POWP showing (1) increased growth performance $\left(G_{\max }=0.24 \times\left[\right.\right.$ POWP] $+19.4, \mathrm{p}<0.01, \mathrm{R}^{2}=$ $0.78)$, and (2) larger variation in $G_{\max }$ values.

\section{Reconstructed time series of bivalve growth}

Time series of SGI and the relative distribution of individuals with positive and negative SGI are presented in Fig. 4. The shorter life span of the individuals found in Disko Bay resulted in shorter time series. In general, the average SGI values reflect the population trend, i.e. a negative SGI for a given year is mostly a

Table 3. Clinocardium ciliatum. Pearson correlation coefficients between time series of bivalve growth variation and measures of sea ice, climate indices (Arctic Oscillation, AO and Arctic Climate Regime Index, ACRI), number of summer days with windspeeds $>10 \mathrm{~m} \mathrm{~s}^{-1}$, and bottom water temperature $(T)$ at Fyllas Band off SW Greenland. Significant correlations $(p<0.05)$ are given in bold. YS = Young Sound; $\mathrm{Qa}=$ Qaanaaq; DB A and B = Disko Bay A and B, respectively

\begin{tabular}{|lcccccc|}
\hline & YS & Qa & DB A & DB B & Nuuk \\
\hline Local ice index & $\mathbf{- 0 . 5 1}$ & $\mathbf{- 0 . 5 3}$ & -0.22 & -0.24 & 0.18 \\
AO & & & & & \\
Annual mean & -0.12 & -0.03 & 0.32 & -0.10 & 0.31 \\
Ann. mean 1 yr lag & -0.02 & -0.09 & 0.11 & -0.21 & 0.24 \\
2 yr running mean & -0.09 & -0.07 & 0.26 & -0.19 & 0.33 \\
ACRI & & & & & \\
Annual mean & -0.03 & 0.12 & 0.05 & 0.08 & -0.03 \\
Ann. mean 1 yr lag & 0.07 & 0.17 & -0.46 & 0.03 & -0.06 \\
2 yr running mean & 0.02 & 0.20 & -0.26 & 0.07 & -0.06 \\
Wind days > 10 m s ${ }^{-1}$ & 0.12 & 0.18 & 0.08 & 0.11 & -0.26 \\
T at Fylla Bank & - & - & - & - & 0.30 \\
& & & & & & \\
\hline
\end{tabular}

result of the majority of the individuals having a negative SGI and not due to a few individuals influencing the mean. Significant negative correlation between summer sea ice index and bivalve SGI was found for Young Sound $\left(\mathrm{p}=0.03, \mathrm{n}=20, \mathrm{R}^{2}=0.26\right)$ and Qaanaaq $\left(p=0.01, n=23, R^{2}=0.28\right)$ (Table 3$)$. No significant correlations between bivalve growth and climatic indices, AO or ACRI, were found (Table 3).

Several of the bivalve sites displayed synchronous patterns in SGI time series (Table 4). A high positive correlation was found between the 2 sites in Disko Bay but also between the 2 high-Arctic sites, Young Sound and Qaanaaq, situated in East and West Greenland. A significant negative correlation was found between

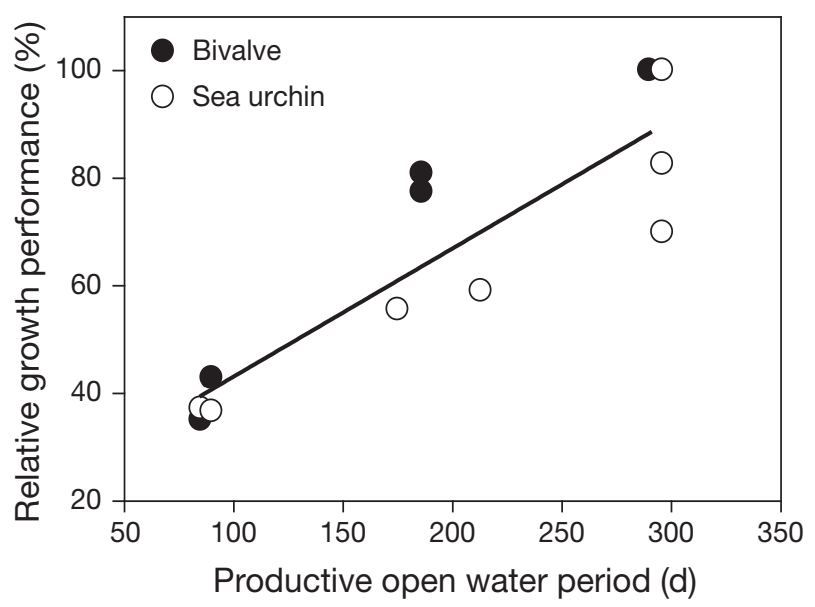

Fig. 6. Growth performance $\left(G_{\max }\right)$ of the bivalve Clinocardium ciliatum estimated as maximum annual shell growth plotted against the productive open-water period (POWP). Data for the sea urchin Strongylocentrotus droebachiensis recalculated from Blicher et al. (2007). Linear regression for the combined species data set: $G_{\max }=0.24 \times[\mathrm{POWP}]+19.4, \mathrm{p}<0.01, \mathrm{R}^{2}=0.78$ 
Table 4. Clinocardium ciliatum. Pairwise Pearson correlations between time series of growth indices reconstructed from analysis of shell increments at different locations in Greenland. Significant correlations are in bold $\left({ }^{*} p<0.05\right.$, $\left.{ }^{* *} p<0.01\right)$. $\mathrm{N}$ is given in parenthesis

\begin{tabular}{|lrrrr|}
\hline & Qaanaaq & $\begin{array}{c}\text { Young } \\
\text { Sound }\end{array}$ & Disko A & Disko B \\
\hline Qaanaaq & & & & \\
Young Sound & $\mathbf{0 . 6 1}^{* *}(27)$ & & & \\
Disko Bay A & $0.07(13)$ & $\mathbf{- 0 . 6 5}^{*}(10)$ & & \\
Disko Bay B & $0.17(17)$ & $\mathbf{- 0 . 6 0 *}(14)$ & $\mathbf{0 . 6 7}^{* *}(15)$ & \\
Nuuk & $0.07(24)$ & $-0.30(21)$ & $0.46(15)$ & $0.42(19)$ \\
\hline
\end{tabular}

Young Sound and the 2 sites in Disko Bay. The growth pattern for bivalves in Nuuk was positively correlated to the bivalve growth pattern at the 2 Disko Bay sites but not significantly so $(p=0.07$ and $p=0.09$ ).

The duplicate time series produced for each of the Disko Bay sites based on external increments on the shell generally showed a pattern very similar to the time series based on increments in the hinge region (Fig. 7). Linear correlation between the duplicate time series was highly significant $(p<0.001)$ and $R^{2}$ was 0.65 and 0.66 for locations A and $\mathrm{B}$, respectively.

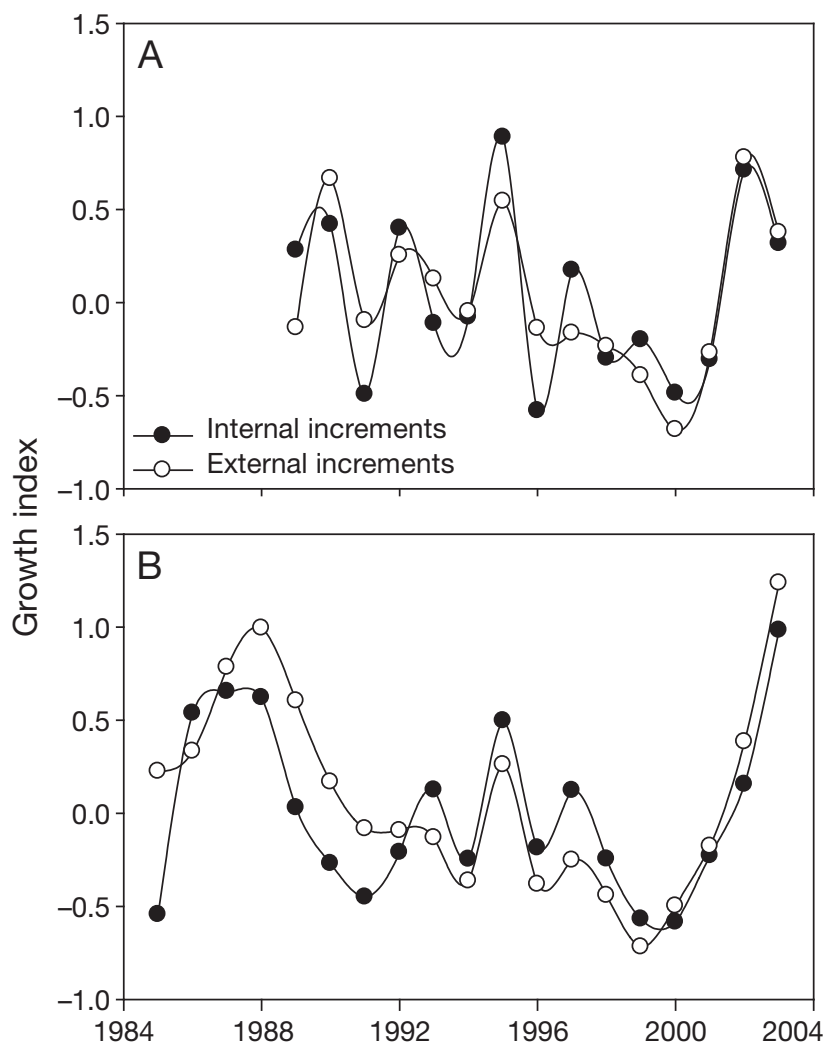

Fig. 7. Clinocardium ciliatum. Comparison of duplicate time series of growth indices (SGI) extracted from 2 separate areas of the shell at 2 sites (A and B) in Disko Bay, West Greenland

\section{DISCUSSION}

\section{Spatial variation in growth}

The clear differences in growth between collection sites are most likely the result of a multitude of environmental factors. Food availability is generally considered the primary constraint on growth in polar benthos (e.g. Blicher et al. 2007, Sejr \& Christensen 2007). The significant relation between the average length of the POWP and bivalve growth indicates that sea ice cover can influence annual growth rates of benthic fauna. We suggest that it could do so by influencing the annual primary production through light limitation, as shown by Rysgaard et al. (1999) and Arrigo et al. (2008). The data available on annual primary production from the studied areas support the idea of sea ice-induced differences in primary productivity. In Young Sound, data from 2001 show that $49.5 \%$ of the annual incoming photosynthetically active radiation (PAR) occurred during the period of sea ice cover, compared with 10 to $15 \%$ in Disko Bay (Sejr et al. 2007). Depending on snow cover, the light under sea ice is reduced to between 0 and $3 \%$ of surface PAR (Sakshaug 2004). Correspondingly, annual phytoplankton production has been estimated at only $10 \mathrm{gC} \mathrm{m}^{-2}$ in Young Sound (Rysgaard et al. 1999) compared with $92 \mathrm{gC} \mathrm{m}^{-2}$ in the Disko Bay (Andersen 1981) and 75 to 160 in Nuuk (Smidt 1979, Mikkelsen et al. 2008a,b). Although no data on annual phytoplankton production are available from Qaanaaq, ice conditions are very similar to those in Young Sound, and primary productivity is most likely comparable at the 2 high-Arctic sites.

In a study on geographical variation in growth rates of the sea urchin Strongylocentrotus droebachiensis (Blicher et al. 2007), maximum annual growth at Qaanaaq and Young Sound was reduced to $~ 40 \%$ compared with growth in Nuuk, which supports the hypothesis concerning the influence of sea ice on marine productivity. However, the present study is based on relatively limited data, which makes it necessary to examine alternative explanations. Food availability unrelated to sea ice cover could also be an important component. For example, the proportion of the pelagic production available to the benthos could differ between sites. This proportion is often related to bathymetry since benthos at depths from 15 to $35 \mathrm{~m}$ are able to feed directly on nutrition-rich subsurface plankton blooms, whereas at greater depths, both the quantity and quality of food reaching the sea floor will be lower due to prior grazing by the pelagic food chain (Wassmann et al. 2004). We attempted to sample at comparable depths to minimize this effect. Unfortunately, specimens in Nuuk were only found between 50 and $60 \mathrm{~m}$. This greater depth is expected to influence the growth estimate from Nuuk negatively. 
Different levels of competition for available food could also influence the observed growth patterns and cannot be ruled out since data on benthic density or biomass are not available from all sites. However, we do not have indications of increased competition in Young Sound and Qaanaaq compared with the other sites.

Temperature is known to be an important regulator of bivalve growth in temperate areas (e.g. Dekker \& Beukema 1999, Witbaard et al. 1999). In Young Sound, the summer temperature at $25 \mathrm{~m}$ depth rarely exceeds $-0.5^{\circ} \mathrm{C}$ (Rysgaard \& Glud 2007). No data are available from Qaanaaq, but it is reasonable to assume a seasonal temperature regime similar to that of Young Sound. In Disko Bay, summer temperature may reach 4 to $4.5^{\circ} \mathrm{C}$ at $25 \mathrm{~m}$ (Nielsen \& Hansen 1999). At the sampling site in Nuuk, temperatures at $50 \mathrm{~m}$ depth show distinct seasonal variation with maximum temperatures of about $4^{\circ} \mathrm{C}$ (M. Blicher unpubl. data). In a shortterm study of a fast-growing Antarctic bivalve, Heilmayer et al. (2005) showed elevated shell growth rates in juveniles kept at $3^{\circ} \mathrm{C}$ compared to a control group kept at $0^{\circ} \mathrm{C}$, which suggests that even small changes in temperature can affect growth.

Factors unrelated to food availability and temperature may also be involved. Parasites can potentially influence growth of bivalves. However, examination of 12 individuals from each of the sites in Disko Bay B and Qaanaaq showed no signs of infection, and parasites do not seem to be a likely explanation of the observed growth patterns.

In conclusion, we suggest that geographical differences in annual growth rate are linked to food availability, which is strongly influenced by the duration of the POWP determined by local sea ice conditions. However, based on this analysis alone, we cannot reject the possibility of temperature being a contributing factor to increased growth performance in bivalves at the sub-Arctic sites.

\section{Inter-annual variation in growth}

Significant correlation between sea ice cover and bivalve growth was found only at the 2 high-Arctic sites: Qaanaaq and Young Sound. Both sites are covered by fast ice every winter and have short periods of open water in summer (Fig. 3). We suggest that the significant correlation between sea ice cover and bivalve growth is a result of the controlling effect of sea ice on phytoplankton production and, hence, food availability for the bivalves. Only at sites with pronounced ice cover will sea ice be important for the inter-annual variation in primary productivity; hence, a significant correlation is found only in Young Sound and Qaanaaq. Insufficient data on annual primary productivity from
Qaanaaq and Young Sound are available for testing whether inter-annual variability is related to ice cover. However, previous studies in Young Sound have shown that light availability is a strong regulating factor of benthic primary production due to the extensive sea ice cover in the area (Borum et al. 2002, Glud et al. 2002, Roberts et al. 2002). Based on satellite data, sea ice dynamics show similar variability at Qaanaaq and Young Sound, which makes it reasonable to assume that variation in sea ice cover will regulate annual primary production and thus bivalve growth equally at these 2 high-Arctic sites. In Disko Bay, the ice cover is far less pronounced and often breaks up during the winter (Fig. 3) and in Nuuk, ice cover is absent most of the year. At these 2 sites, the annual primary productivity is not strongly coupled to light availability but potentially to factors such as water column stability and nutrient availability (Nielsen \& Hansen 1999). Such factors can also cause variation in annual primary production and affect bivalve growth. In Nuuk, the annual primary production at the same site was 75 and $104 \mathrm{~g} \mathrm{C} \mathrm{m}^{-2} \mathrm{yr}^{-1}$ in 2006 and 2007 (Mikkelsen 2008b) and the inter-annual variation in bivalve growth is comparable to the more northern sites. Nutrient availability is generally determined by the concentration in the surface layer prior to the spring bloom (Sakshaug 2004). Secondary blooms can, however, develop later in the season following a period with strong winds causing upwelling of nutrient-rich water (Nielsen \& Hansen 1999, Sakshaug 2004). We correlated bivalve growth to the number of summer days with wind speeds $>10 \mathrm{~m} \mathrm{~s}^{-1}$, extracted from Cappelen et al. (2000). Although wind data in single years are missing, no significant correlation was found for any of the bivalve sites (Table 4). To test for a complex effect of several features of climate, bivalve growth was correlated to the AO and the ACRI, but no significant correlation with growth was found in any of the bivalve sites.

Temperature might cause variation in growth rates as discussed previously; however, we found no significant correlation between our bivalve growth index in Nuuk and the temperature time series at the nearby Fyllas Bank. At sites further north, seasonal and interannual variability in temperature are smaller, suggesting that temperature is not important for the interannual variation in bivalve growth at these high latitudes.

The lack of correlation with physical factors suggests that biological interactions could be important for inter-annual variation in growth. In a study from the North Sea on the bivalve Arctica islandica, no direct link could be established between long-term growth data and phytoplankton biomass because food availability was modified by copepod abundance (Witbaard et al. 2003). Although the bivalves in this study were 
sampled at relatively shallow depths and thus graze directly on sub-surface plankton blooms, it is welldocumented that copepods can control phytoplankton stocks through grazing (Rysgaard et al. 1999) and, thus, influence food availability for the benthos.

We are aware of 2 other studies that have attempted to establish a link between sea ice and bivalve growth in the Arctic. Using the same species, Tallqvist \& Sundet (2000) sampled 3 sites in the Barents Sea without finding a significant correlation with ice cover. Two possible explanations are: (1) None of the sites sampled in the Barents Sea seem to be covered by seasonal fast ice to the extent found in Young Sound and Qaanaaq (satellite data extracted in this study; data not shown). Even at the very northern location ('Moffen' at $80^{\circ} \mathrm{N}$ in Svalbard) sea ice cover was much less pronounced compared to Qaanaaq and Young Sound. (2) Sampling depth was greater (80 to $130 \mathrm{~m}$ ), which potentially weakens the pelagic benthic coupling. In another study from a Svalbard fjord with ice conditions comparable to those in Young Sound and Qaanaaq, inter-annual variation in growth of Serripes groenlandicus was partly related to large-scale sea ice data when excluding the last $4 \mathrm{yr}$ of a $20 \mathrm{yr}$ time-series (Ambrose et al. 2006).

\section{Evaluation of time series}

When attempting to reconstruct growth patterns from increment analysis and relate results to largescale factors such as sea ice, at least 3 important aspects must be considered: (1) Are the increments formed annually? (2) Are the increment measurements and age determinations precise and reliable? (3) Do the collected specimens display a common synchronous signal that can meaningfully be correlated with climatic factors operating on a large scale? For this species, the annual formation of increments has not been tested experimentally; however, evidence from other Arctic species (Sejr et al. 2002b, Ambrose et al. 2006) suggests that the pronounced seasonal input of food makes annual increments a common feature in Arctic bivalves. Also, age determinations as well as growth equations give results comparable to those found in other Arctic bivalves, which makes it reasonable to assume that increments are formed annually (see also Tallqvist \& Sundet 2000).

Testing whether a group of individuals exhibits a common synchronous growth signal is not straightforward. We have found it useful to analyse a sufficient number of individuals to calculate a robust average. It also allows the proportion of individuals displaying positive/negative values to be calculated. This makes it possible to check that average SGI values also corre- spond to a general pattern in the sample and is not a result of a few outliers. Finally, the fact that bivalves were sampled at 2 locations separated by a few kilometres (Disko Bay A and Disko Bay B) and the finding of a significant positive correlation between the constructed time series strongly suggest that large-scale factors do play an important role for the inter-annual variation in bivalve growth at least in these 2 locations. Hence, we believe there is sufficient evidence that the reconstructed time series are valid indicators of past growth conditions.

\section{CONCLUSIONS}

The combined results from the geographical and inter-annual variation in growth indicate that summer growth of the bivalve Clinocardium ciliatum is linked to sea-ice dynamics at sites with pronounced sea ice cover. We suggest that this link is created through bottom-up regulation of the annual phytoplankton production. At sites with prolonged sea ice cover, bivalve growth is primarily limited by food due to low primary production. At sites with moderate ice cover, bivalve growth will, to a larger extent, be influenced by a multitude of physical and biological factors affecting primary production and benthic food availability. Additional studies are necessary to improve our understanding of how the complex interactions between physical and biological parameters governing benthic productivity are linked to sea ice cover in the Arctic and to confirm whether sea ice does indeed directly influence growth rates of benthic macrofauna through bottom-up regulation of phytoplankton production.

Acknowledgements. This study was financially supported by DANCEA (project 127/001-0011) and The Commission for Scientific Research in Greenland. L. Toudal is thanked for extracting sea ice data, and K. T. Jensen is acknowledged for checking specimens for parasites. G. Asmund is thanked for collecting specimens near Qaanaaq and A. Haxen is acknowledged for linguistic corrections. Four anonymous reviewers provided valuable comments on earlier versions of the manuscript. The study is a contribution to the Greenland Ecosystem Monitoring Program (www.g-e-m.dk) and Arctic Tipping Points (www.eu-atp.org)

\section{LITERATURE CITED}

Ambrose WG, Carroll ML, Greenacre M, Thorrold SR, McMahon KW (2006) Variation in Serripes groenlandicus (Bivalvia) growth in a Norwegian high-Arctic fjord: evidence for local- and large-scale climatic forcing. Glob Change Biol 12:1595-1607

Andersen O (1981) The annual cycle of phytoplankton primary production and hydrography in the Disko Bugt area, West Greenland. Medd Gronl Biosci 6:3-65 
Arrigo KR, van Dijken G, Pabi S (2008) Impact of a shrinking Arctic ice cover on marine primary production. Geophys Res Lett 35:L19603. doi:10.1029/2008GL035028

Blicher ME, Rysgaard S, Sejr MK (2007) Growth and production of the sea urchin Strongylocentrotus droebachiensis in a high-Arctic fjord, and growth along a climatic gradient $\left(64-77^{\circ} \mathrm{N}\right)$. Mar Ecol Prog Ser 341:89-102

Borum J, Pedersen MF, Krause-Jensen D, Christensen PB, Nielsen K (2002) Biomass, photosynthesis and growth of Laminaria saccharina in a high-arctic fjord, NE Greenland. Mar Biol 141:11-19

Cappelen J, Jørgensen BV, Laursen EV, Stannius LS, Thomsen RS (2000) The observed climate of Greenland, 1958-99 — with climatological standard normals, 19611990. DMI Tech Rep 00-18, Copenhagen

Clarke A (1988) Seasonality in the Antarctic marine environment. Comp Biochem Physiol 90B:461-473

Clarke A, Fraser K (2004) Why does metabolism scale with temperature? Funct Ecol 18:243-251

> Dekker R, Beukema J (1999) Relations of summer and winter temperatures with dynamics and growth of two bivalves, Tellina tenuis and Abra tenuis, on the northern edge of their intertidal distribution. J Sea Res 42:207-220

Gloerson P, Cavalieri D, Campbell WJ, Zwally J (1990) Nimbus-7 SMMR polar radiances and Arctic and Antarctic sea ice concentrations. CD-ROM. National Snow and Ice Data Center, Boulder, $\mathrm{CO}$

Glud RN, Kühl M, Wenzhöfer F, Rysgaard S (2002) Benthic diatoms in a high Arctic fjord (Young Sound, NE Greenland): importance for ecosystem primary production. Mar Ecol Prog Ser 238:15-29

Goshima S, Noda T (1992) Shell growth of the North Pacific cockle Clinocardium californiense in Hakodate Bay, Hokkaido. Benthos Res 42:39-48

Grebmeier JM, McRoy PC, Feder HM (1988) Pelagic-benthic coupling on the shelf of the northern Bering and Chukchi Seas. I. Food supply source and benthic biomass. Mar Ecol Prog Ser 48:57-67

Heilmayer O, Honnen C, Jacob U, Chiantore M, CattaneoVietti R, Brey T (2005) Temperature effects on summer growth rates in the Antarctic scallop, Adamussium colbecki. Polar Biol 28:523-527

National Snow and Ice Data Center (2007) Arctic sea ice shatters all previous record lows. Boulder, CO. www. nsidc.org/news/press/2007_seaiceminimum/20071001_ pressrelease.html

Maslanik J, Stroeve J (2004) DMSP SSM/I daily polar gridded sea ice concentrations, July 1987 to October 2004. CDROM. National Snow and Ice Data Center, Boulder, CO

Mikkelsen DM, Rysgaard S, Glud R (2008a) Microalgal composition and primary production in Arctic sea ice: a seasonal study from Kobbefjord (Kangerlauarsunnguaq), West Greenland. Mar Ecol Prog Ser 368:65-74

Mikkelsen DM, Rysgaard S, Mortensen J, Retzel A and 12 others (2008b) Nuuk Basic: The MarineBasic Programme 2007. In: Jensen, LM, Rasch, M (eds.) Nuuk Ecological Research Operations, 1st Annual Report, 2007. Danish Polar Centre, Danish Agency for Science, Technology and Innovation, Ministry of Science, Technology and Innovation, Copenhagen, p 54-74

Nielsen TG, Hansen BW (1999) Plankton community structure and carbon cycling on the western coast of Greenland during the stratified summer situation. I. Hydrography, phytoplankton and bacterioplankton. Aquat Microb Ecol 16:205-216
Proshutinsky A, Johnson M (1997) Two circulation regimes of the wind-driven Arctic Ocean. J Geophys Res 102: 12493-12512

Renaud PE, Morata N, Ambrose WG, Bowie JJ, Chiuchiolo A (2007) Carbon cycling by seafloor communities on the eastern Beaufort Sea shelf. J Exp Mar Biol Ecol 349: $248-260$

Richter-Menge J, and 44 others (2008) Arctic Report Card 2008 www.arctic.noaa.gov/reportcard

Roberts RD, Kühl M, Glud RN, Rysgaard S (2002) Primary production of crustose coralline red algae in a high Arctic fjord. J Phycol 38:273-283

Rysgaard S, Glud RN (2007) Carbon cycling and climate change: predictions for a high Arctic marine ecosystem (Young Sound, NE Greenland). Medd Gronl Biosci 58: 206-213

Rysgaard S, Nielsen TG, Hansen BW (1999) Seasonal variation in nutrients, pelagic primary production and grazing in a high-Arctic coastal marine ecosystem, Young Sound, Northeast Greenland. Mar Ecol Prog Ser 179:13-25

Sakshaug E (2004) Primary and secondary production in the Arctic Seas. In: Stein R, Macdonald RW (eds) The organic carbon cycle in the Arctic Ocean. Springer, Berlin-Heidelberg, p 57-81

Schöne B (2003) A 'clam-ring' master chronology constructed from a short-lived bivalve mollusc from the northern Gulf of California, USA. Holocene 13:39-49

Sejr MK, Christensen PB (2007) Growth, production and carbon demand of macrofauna in Young Sound, with special emphasis on the bivalves Hiatella arctica and Mya truncata. In: Rysgaard S, Glud RN (eds) Carbon cycling in Arctic marine ecosystems: Case study Young Sound. Medd Grønl Biosci Special Issue, p 121-137

Sejr MK, Jensen KT, Rysgaard S (2002a) Annual growth bands in the bivalve Hiatella arctica validated by a markrecapture study in NE Greenland. Polar Biol 25:794-796

Sejr MK, Sand MK, Jensen KT, Petersen JK, Christensen PB, Rysgaard S (2002b) Growth and production of Hiatella arctica (Bivalvia) in a high-Arctic fjord (Young Sound, Northeast Greenland). Mar Ecol Prog Ser 244:163-169

> Sejr MK, Petersen JK, Jensen KT, Rysgaard S (2004) Effects of food concentration on clearance rate and energy budget of the arctic bivalve Hiatella arctica (L) at subzero temperature. J Exp Mar Biol Ecol 311:171-183

> Sejr MK, Nielsen TG, Rysgaard S, Risgaard-Petersen N, Sturluson M, Blicher ME (2007) Fate of pelagic organic carbon and importance of pelagic-benthic coupling in a shallow cove in Disko Bay, West Greenland. Mar Ecol Prog Ser 341:75-88

Smidt E (1979) Annual cycles of primary production and of zooplankton at southwest Greenland. Medd Grønl Biosci 1

Tallqvist ME, Sundet JH (2000) Annual growth of the cockle Clinocardium ciliatum in the Norwegian Arctic (Svalbard area). Hydrobiologia 440:331-338

Wassmann P, Bauerfeind E, Fortier M, Fukuchi M, and others (2004) Particulate organic carbon flux to the Arctic Ocean Sea floor. In: Stein R, Macdonald RW (eds) The organic carbon cycle in the Arctic Ocean. Springer, Berlin-Heidelberg, p 101-138

Witbaard R, Duineveld GCA, de Wilde PAWJ (1999) Geographical differences in growth rates of Arctica islandica (Mollusca: Bivalvia) from the North Sea and adjacent waters. J Mar Biol Assoc UK 79:907-915

Witbaard A, Jansma E, Saas Klaassen U (2003) Copepods link quahog growth to climate. J Sea Res 50:77-83

Submitted: January 12, 2009; Accepted: July 6, 2009

Proofs received from author(s): August 24, 2009
Editorial responsibility: Hans Heinrich Janssen, Oldendorf/Luhe, Germany 